This item was submitted to Loughborough's Research Repository by the author.

Items in Figshare are protected by copyright, with all rights reserved, unless otherwise indicated.

\title{
Do board directors affect the export orientation and export performance of Korean firms? A resource dependence perspective
}

PLEASE CITE THE PUBLISHED VERSION

https://doi.org/10.1016/j.ibusrev.2017.08.001

\section{PUBLISHER}

(C) Elsevier

\section{VERSION}

AM (Accepted Manuscript)

\section{PUBLISHER STATEMENT}

This work is made available according to the conditions of the Creative Commons Attribution-NonCommercialNoDerivatives 4.0 International (CC BY-NC-ND 4.0) licence. Full details of this licence are available at: https://creativecommons.org/licenses/by-nc-nd/4.0/

\section{LICENCE}

CC BY-NC-ND 4.0

\section{REPOSITORY RECORD}

Nam, Jonghoon, Xiaohui Liu, Eleni Lioliou, and Mugoan Jeong. 2019. "Do Board Directors Affect the Export Orientation and Export Performance of Korean Firms? A Resource Dependence Perspective". figshare. https://hdl.handle.net/2134/26204. 


\title{
Do Board Directors Affect the Export Orientation and Export \\ Performance of Korean Firms? A Resource Dependence Perspective
}

\author{
Jonghoon Nam a, Xiaohui Liu b1, Eleni Lioliou c, Mugoan Jeong d \\ ${ }^{\text {a }}$ School of Business and Economics, Loughborough University, Loughborough LE11 \\ 3TU, UK, phone:+44 (0)7931379692, email: j.h.nam@lboro.ac.uk \\ ${ }^{\mathrm{b}}$ School of Business and Economics, Loughborough University, Loughborough LE11 \\ 3TU, UK, phone: +44 (0)1509 223349, email: x.liu2@lboro.ac.uk \\ c School of Business and Economics, Loughborough University, Loughborough LE11 \\ 3TU, UK, phone: +44 (0)1509 223106, email: e.lioliou@lboro.ac.uk \\ ${ }^{\mathrm{d}}$ College of Economics and Commerce, Kyungnam University, 7 Kyungnamdaehak-ro, \\ Masanhappogu, 631-701, Changwon-Si, Korea, phone:+82 (55) 2492487 \\ email: duryjmg@kyungnam.ac.kr
}

${ }^{1}$ Corresponding author: Xiaohui Liu: x.liu2@lboro.ac.uk 


\title{
Do Board Directors Affect the Export Propensity and Export Performance of Korean Firms? A Resource Dependence Perspective
}

\begin{abstract}
Using the Heckman two-stage method, this study empirically investigates whether board directors' work experience in government and multinational corporations (MNCs), as well as the proportion of outside directors affects export propensity and export performance based on a sample of Korean firms. We find that the Korean firms with former government officials on the board are more likely to engage in exporting, although there is no empirical evidence supporting export performance. The findings also show that firms with former MNC employees on the board demonstrate higher levels of export propensity and export performance. Similarly, firms with a higher proportion of outside directors exhibit a higher level of export propensity and export performance. These findings highlight the importance of the board of directors in Korean firms' first stage of internationalization and provide new insights into which type of board members can benefit their firms in terms of export propensity and export performance.
\end{abstract}

Key words: resource dependence, exports, government experienced board directors, MNC experience, outside directors; Korea 


\section{Introduction}

Exporting is considered as the first step to internationalization because it requires the commitment of minimal resources, involves lower risks compared to other international strategies and allows for greater flexibility (Czinkota \& Ronkainen, 2007; Leonidou, Palihawadana, \& Theodosiou, 2011). Firms engaging in exporting, however, encounter various obstacles that may negatively affect their overall performance (Leonidou, Palihawadana, \& Theodosiou, 2011). Obstacles to exporting are associated both with internal resource constraints and external barriers (Leonidou, 1995a; Miesenbock, 1988). Contemporary organizations, therefore, are constantly leveraging internal resources and seeking external resources that will enable them to overcome the barriers to exporting, mitigate the associated risks and boost export performance.

Previous studies on export performance have tended to focus on various aspects related to firms' capabilities, industry competition and institutional environments (Buck, et al., 2007; Chen, Sousa, \& He, 2016; Gao, et al., 2010). A major limitation of this stream of research is that it has overlooked the role of the board of directors in facilitating export performance (Herrera-Echeverri, et al, 2016; Barroso, et al, 2011). Despite the role that the board of directors plays in achieving key organizational outcomes, such as exporting, our understanding of the relationship between the board of directors and export performance remains relatively fragmented (Herrera-Echeverri et al, 2016; Barroso, et al, 2016; Rivas et al, 2009).

A related issue is that prior literature in corporate governance has mainly focused on examining the role of the board of directors in enhancing firm financial performance (Chizema et al., 2015; Hillman, Withers, \& Collins, 2009; Johnson, Daily, \& Ellstrand, 1996; 
Liu, Wei, \& Xie, 2014, Ntim, 2015) and firm value (Ntim, Opong, \& Danbolt, 2012a). There is less research examining the effect of the board of directors on other types of business activities, such as exporting. In particular, the extent to which the composition of the board of directors affects exporting is underexplored (Rivas, 2012a, 2012b; Rivas, Hamori, \& Mayo, 2009; Sanders \& Carpenters, 1998). This neglect, therefore, limits our understanding of which types of board directors can benefit exporting.

Another limitation of prior literature is that although it has extensively recognized the monitoring or governance role of the board of directors, as suggested by agency theory (Hillman, Cannella, \& Paetzold, 2000; Pfeffer \& Salancik, 1978), it has overlooked board directors' resource provision role, especially in supporting exporting (Hillman, Withers, \& Collins, 2009; López Rodríguez and García Rodríguez, 2005). In the context of international business (IB), this neglect is paradoxical, as the role of a board in gaining access to specialized knowledge concerning foreign markets and acquiring other types of resources necessary for exporting can be crucial (Rivas, 2012a, 2012b; Rivas, Hamori, \& Mayo, 2009).

A further weakness of previous investigation in this area is that much research has focused on Western contexts (Chizema et al., 2015; Ntim, Lindop, \& Thomas, 2013; Ntim, Opong, \& Danbolt, 2015). However, corporate governance mechanisms, such as the board of directors in emerging countries, differ from those in Western countries (Buck, Liu \& Skovoroda, 2008; Chizema et al., 2015; Ntim, Opong, \& Danbolt, 2015). There have been many regulatory changes aimed at improving the effectiveness of corporate governance in many emerging countries (Chizema et al., 2015). Such changes are very prominent in Asia, as a result of the Asian financial crisis in 1997-1998. It is widely recognized that Asian corporate governance differs from the Anglo-American model and German model and, hence, an investigation into the role of directors in the Asian context is crucial in order to better 
understand the resource provision role of the board of directors in exporting. In particular, the Korean government leads the market economy system, and the relationship between businesses and the government is closely intertwined. Government officials can use their power to provide preferential treatment for the firms with which they have developed close links. Seeking crucial resources from the government through political ties is a fact of Korean business life (Siegel, 2007). Such an institutional setting makes the role of the board of directors even more pivotal in gaining access to the external resources needed for exporting. Thus, Korea represents an interesting and important context for such an investigation.

To address the research gaps identified above, we aim to investigate the role of the board of directors as resource providers in exporting by adopting a resource dependence perspective based on a sample of Korean firms. Specifically, we examine to what extent a board's specific characteristics and outside directors affect a firm's export propensity and export performance.

Our paper makes three main contributions to IB and corporate governance research. First, this study reveals that the role of the board of directors is more than just monitoring and controlling, thus expanding our understanding of the impact of the board of directors as critical resource providers on exporting. Specifically, we focus on two types of board directors: those who are former government officials, and those who have multinational corporation (MNC) experience. In doing so, this study delineates the resource dependence logic of board directors and offers new insights into which type of board members can be of benefit to their firms’ export propensity and export performance.

Second, we examine the unique context of Korea, where so far there has been scarce academic investigation. Our study extends prior research based on developed country contexts to the Korean context and sheds new light on the effects of the unique institutional 
characteristics of Korea, as well as the government imposed changes on the composition of company boards, particularly with regard to their impact on the firms' export propensity and export performance. Our research responds to the call for more context-specific approaches in the study of board directors (Ntim et al., 2015; Chizema et al., 2015).

Finally, this study adds much needed empirical evidence on the link between the board of directors and exporting in the Korean context. We have adopted the Heckman two-stage model to control for endogeneity problems. Moreover, we have provided additional evidence on the impact of different types of the board of directors on export propensity and performance using the simultaneous quantile regression.

\section{Research context}

The Asian financial crisis in 1997-1998 led many countries in the continent to undertake significant corporate governance reforms. These reforms did not completely follow the Western models of corporate governance and, for this reason, studies into corporate governance, such as the role of board directors should pay particular attention to the unique features of the Asian context (Chizema et al, 2015; Lu, Xu, \& Liu, 2009). Thus, in this section, we present three unique institutional characteristics of corporate governance in the Korean context.

First, the Korean government has historically implemented various policies to support exporting and has played a dominant role in firm internationalization (Chang \& Hong, 2002). Elite public officials have access to significant government-related resources (including information on public policy changes, government funds, links to government owned financial institutions etc.). When retired public officials move to work for private firms they 
are able to utilize their links to the government, work as lobbyists and receive preferential treatment. These former government officials can support firms by obtaining resources from their previous government bodies called 'jeongwan yeu'. Such resources include important information in relation to government policy changes, but also other government-related resources such as trade finance and trade insurance from the state-owned banks and institutions (Anti-Corruption \& Civil Rights Commission of Korea, 2012). According to the Anti-Corruption \& Civil Rights Commission of Korea (2012), these former government officials are well known in Korea both for their networks and contacts in the public sector, but also their ability to lobby in favour of the companies that they later on work for.

Second, the Asian financial crisis impacted on Korean firms' recruiting strategies to shift the emphasis from hiring lifetime employees to recruiting experienced employees (Kim \& Kim, 2003; Kim \& Yu, 2000). Before the Asian financial crisis, Korean firms dominated the Korean market. However, a number of Korean firms were sold to MNCs such as GM and Renault during the financial crisis (Chang, 2006). Spontaneously, Korean firms tried to hire MNC-experienced board members in order to benefit from their international experience and the MNCs networks with which they had previously worked (Bae et al., 2003). Thus, this new trend in the hiring strategy adopted by Korean firms after the Asian financial crisis raises an important research question with regard to the role of board members with MNC experience in their firms’ export propensity and export performance.

Third, the reform of corporate governance regulations in Korea after the Asian financial crisis required Korean firms to have at least 25\% of their boards made up of outside directors. This development resulted from changes in the Commercial Code in 1998 and the Securities and Exchange Act in 1999. Furthermore, the International Monetary Fund (IMF) obliged large Korean firms with total assets over two trillion Korean won to be composed of at least 
50\% outside directors (Chizema \& Kim, 2010). Given the importance of the board system, its relatively short history in the Korean economy, and the rapid changes in related government regulations, we maintain that the Korean context represents a unique but also immensely fruitful setting for investigation.

\section{Theoretical Framework}

Pfeffer and Salancik (1978) introduced RDT to explain how organizations reduce environmental interdependence and uncertainty. According to RDT, organizations are open systems which are not self-sufficient due to their dependence on the external environment to gain the material or symbolic resources that they require (Durand \& Jourdan, 2012; Pfeffer \& Salancik, 1978). To ensure their existence and their sustainable growth, organizations must manage environmental demands to secure a stable supply of critical resources, such as financial capital, production inputs and legitimacy. Organizations are both supported and constrained by their external environments (Garud, Jain \& Kumaraswamy, 2002; Oliver, 1991). Thus, successful organizations must develop ways to effectively cope with their environmental needs, manage resource dependencies and counteract the power of key resource holders (Pfeffer \& Salancik, 1978).

From an RDT perspective, the government and its agencies constitute a source of scarce resources sought by firms, and a dependency situation arises when firms rely on crucial resources controlled by government (Pfeffer \& Salancik, 1978). The board of directors is appointed to facilitate access to various external resources controlled by the government, and

reduce environmental uncertainty. Given that exporters need to obtain diverse resources from 
outside organizations to alleviate uncertainty (Tesfom, Lutz, \& Ghauri, 2004), RDT provides a useful lens with which to examine the determinants of a firm's export performance.

The board of directors can contribute various resources that will facilitate a firm's internationalization strategy (George, Wiklund, \& Zahra, 2005; Hillman, Cannella, \& Paetzold, 2000). Rivas (2012a) argues that the diversity of the board can lessen internationalization-related uncertainty by exploiting directors’ diverse knowledge, skills and abilities. Given that successful internationalization requires a multidimensional approach to reduce costs and environmental complexity (George, Wiklund, \& Zahra, 2005), Rivas’s study has particular implications for the current study because the resources that boards provide to the firm are associated with their knowledge, experience, skills, and social networks. Based on the above theoretical perspective, we propose and test a number of hypotheses by focusing on the extent to which different types of boards affect exports, especially the export propensity and export performance of Korean firms.

A few studies have examined Asian firms' first steps towards internationalization measured by export propensity and export performance. Based on a sample of Chinese firms, Filatotchev, et al. (2009) and Gao et al. (2010) focused on the impact of firms' internal resources on export propensity and export performance by adopting the knowledge based view and RBV, respectively. Buck et al. (2007) explored Chinese firms' export propensity and export performance based on Dunning's trade development path. Similarly, Zhao and Zou (2002) examined the impact firm specific internal factors such as firm size and capital intensity have on export propensity and export performance. Despite the fact that board directors bring scarce resources from external organizations (Hillman, Cannella, \& Paetzold, 2000; Pfeffer \& Salancik, 1978), extant literature in the Asian context has overlooked board directors' resource provision role, which is crucial for successful exporting (Rodríguez \& 
Rodríguez, 2005). In particular, the government leads the market economy system and is heavily involved in developing an export-oriented economy in the Asian context (Chang \& Hong, 2000).

\section{Hypotheses Development}

\subsection{Government experience and exporting}

From an RDT perspective, a firm needs to exploit external resources to reduce environmental uncertainty and achieve sustainable competitiveness (Hillman and Dalziel, 2003). The availability of external resources may vary depending on a firm's business environment, especially with the government being considered the most important resource provider. Firms are frequently influenced by government in many business aspects (Hillman, 2005). A good relationship with the government, therefore, is one of the most significant resources for contemporary organizations. In this respect, the employment of a former government official as a board member can be a very significant resource that will bring links to the government as well as political experience.

A large body of research, stemming from an RDT perspective, supported these insights. Schuler, Rehbein, and Cramer (2002) noted that organizational members with government experience are regarded as salient sources of competitive advantage for firms. Hillman, Canella, and Paetzold (2000) proposed that government-connected boards provide their firms with intangible resources, such as valuable information and access to key officials who influence their business. Hillman and Hitt (1999) also found that firms with former government officials on their boards enjoy better performance than those lacking such directors. 
In our study, therefore, we adopt an RDT perspective and focus on the role of former government officials in their firm's internationalization efforts. Specifically, we argue that in Korea a firm's export propensity and export performance are likely to be influenced by boards with government experience. To understand the effect of this specific type of board on export propensity and export performance, it is essential to understand the unique Korean institutional context and its history, as well as how the execution of corporate governance in Korea has developed over time.

As a part of the Economic Development Plan pursued by the Korean government in the 1960s, large Korean firms were given preferential treatment, such as loans with lower interest rates, despite high inflation (Chang \& Choi, 1988). A typical example was the support for exporting industries. The economic plan and the accompanying export inducements have made the government an established source of export-related support, inducing firms' dependency on those resources (Chang \& Hong, 2000).

Under this institutional environment, we argue that the government-connected boards are able to exert more influence on their firms' exports. This claim can be explained by particular Korean social practices and systems as follows. First, Korea has a unique culture called 'jeongwan yeu'. This term has almost the same meaning as the Chinese 'guanxi', which represents close connections between firm managers and government officers based on the Confucian culture of alleviating uncertainty and generating business opportunities (Park \& Luo, 2001). The Anti-Corruption \& Civil Rights Commission of Korea (2012, p. 13) defines 'jeongwan yeu' as 'retired public officials who enter law firms or private companies who may act as a lobbyist by using the social networks which they had established during the occupancy of their post.' Since the practice of 'jeongwan yeu' is deeply rooted in the Korean business environment, we can expect a firm to hire former public officials to lobby 
government agencies on behalf of its own interests and to seek government support in order to exploit international business opportunities. It is important to note that as part of this culture, Korean companies are aggressively competing to recruit such former government officials and create strong links with the government. In this manner, companies are trying to promote their own interests and are lobbying for particular government policies against others. Thus, boards with former Korean officials can act as crucial resource providers for their firms.

Second, there is also a particular government appointment system called 'gosi', which refers to a national civil service examination to select public officers. Traditionally, Korean economic development has relied on the powerful political leadership of elite officials with bureaucratic top-down communication (Ha \& Kang, 2010). In the context of a firm's export activity, former public officials through 'gosi' exploit the human and social capital they have accumulated during their time in public positions to create a favourable relationship between their firms and export-related government bodies, and seek to obtain viable export resources such as export finance and export insurance. Government-affiliated banks and institutions have played an important role in Korean firms' export activities. The Export-Import Bank of Korea provides diverse financial products for Korean exporters, such as export credit and overseas investment credit. The Korea Trade Insurance Corporation (KEIC) also offers multiple short-term and medium-term products for both exporters and foreign buyers in order to boost Korean firms' export performance (e.g. short-term export credit insurance) and to help foreign buyers to import Korean products (e.g. short-term export insurance, buyer credit). Conventionally, former ministers or high-ranking post holders, 'gosi' background officials at the Ministry of Strategy and Finance and the Ministry of Trade, Industry and Energy move to take on high-rank posts in government-affiliated banks and institutions in 
Korea. Thus, by leveraging their 'gosi' networks with these state-owned institutions, former public officials from 'gosi' can secure better export-related financial support than those without such experience.

Overall, an RDT perspective illuminates the fact that former public officials are likely to serve as intermediaries who bring with them critical resources and information relevant to the government and its policies (Chizema et al., 2015). In turn, they significantly impact on their firms' export propensity and performance. Furthermore, in Korea, where the practice of 'jeongwan yeu' is rooted across society beyond the role as resource providers, former officials are most likely to attempt to actively change the business environment more favourably for their own firm through lobbying the government against adverse policies. Based on the aforementioned discussion, we therefore posit the following hypotheses:

Hypothesis 1a: A Korean firm's export propensity is positively associated with the presence of a board member with government experience.

Hypothesis 1b: A Korean firm's export performance is positively associated with the presence of a board member with government experience.

\subsection{MNC experience and exporting}

Firms operating in international markets perform differently and this partly results from the different resources they possess and/or manage to obtain in order to reduce uncertainty in the external environment. From an RDT perspective, successful firms will manage to acquire resources that will facilitate their internationalization efforts. Firms engaged in exporting need to develop expertise and knowledge of international markets that will help them act on 
international business opportunities (Eriksson et al., 1997). In particular, exporting requires specific knowledge of how to identify and serve foreign customers.

According to McDougall, Oviatt, and Shrader (2003) board members with MNC experience possess significant knowledge about international markets and trade regulations. They may also have developed some external ties and relational capital that can be very significant in international business activities (Iriyama \& Madhavan, 2014). Board members with MNC experience have been regarded as linkage brokers with other organizations and their contribution in bringing crucial resources and information needed for their firm's export success has been highly emphasized (Gulati, 1995; Iriyama \& Madhavan, 2014). Moreover, these board directors act as a channel for export spillovers whereby technology, management skills and international marketing techniques may be transferred to parent firms, thus positively affecting parent firms' export propensity and export performance (Filatotchev et al., 2009).

Furthermore, a board member with MNC experience will have developed critical relationships with local regulators, financial institutions, high-ranking politicians and government officials. Board members with MNC experience, therefore, will be able to provide critical contacts, information and tangible resources to facilitate their firm's export activities. For example, a board with MNC experience can effectively alleviate export-related uncertainty and obstacles by contributing scarce information gleaned from the international networks they developed in their prior work in exporting countries (Iriyama \& Madhavan, 2014; Luo, 2005). They can also facilitate various favourable international loans and insurance from local financial institutions, and even access information on cutting-edge technology from previous workplaces in order to initiate exports or to increase export sales (Luo, Xue, \& Han, 2010). 
A body of research has documented the impact of executives with MNC experience on various aspects of a firm. Daily, Certo, and Dalton (2000), Roth (1995), and Athanassiou and Nigh (2002) show that a firm that has former MNC executives on its board increases its competitive advantage by using their previous business networks, as well as their capacity to access critical information, both of which enable a firm to effectively operate and expand its overseas business. Consistent with this view, Ghoshal and Bartlett (1990) reported that a board member who has work experience in an MNC has strong job-related connections with client firms, subcontractors and regulators. Thus, it is possible that these boards can utilize the previous networks of the directors to develop potential strategic partners for their current firm to facilitate exports. Lee and MacMillan (2008) underscore that MNCs not only widely share standardized training programmes, but also provide appropriate and customized training from headquarters to help employees learn global business practices. Therefore, board members with MNC experience may act as messengers able to transfer advanced training and know-how to the current firm they serve, and help the firm adopt international business practices which enhance export propensity and export performance.

Regarding the Korean context during the Asian financial crisis, the Korean government had to deregulate its domestic market in order to receive IMF relief loans. As a result, GM acquired Daewoo Motors, Volvo acquired Samsung’s heavy equipment, and Renault acquired Samsung Motors (Chang, 2006). Consequently, many Koreans had the chance to work in global-leading MNCs and many Korean firms have adopted an American-style HR management system since the Asian financial crisis (Kim \& Kim, 2003; Kim \& Yu, 2000). One of these Western HR practices pursued by Korean firms is a corporate hiring policy to recruit highly specialized employees that do not require training in order to improve global competitiveness and workplace efficiency (Bae et al., 2003; Tayeb, 1998). By fully exploiting 
their previous experience and social networks in international business, board members with MNC experience can extract valuable resources related to foreign trade from organisations located in exporting countries. In this sense, board members with MNC experience help the firm obtain the necessary capital to facilitate exporting. A board of directors with MNC experience possesses valuable human and social capital and therefore can have better access to resources, such as relevant market information and connections with local governments (Filatotchev et al., 2009). Thus, we hypothesize:

Hypothesis 2a: A Korean firm’s export propensity is positively associated with a board's MNC experience.

Hypothesis 2b: A Korean firm's export performance is positively associated with a board's MNC experience.

\subsection{Outside directors and exporting}

According to RDT theorists, the outside directors of a firm are expected to help to absorb and address the environmental uncertainty facing the firm (Boyd, 1990; Hillman, Cannella, \& Paetzold, 2000). Pfeffer and Salancik (1978, p. 163) noted that “...when an organization appoints an individual to a board, it expects the individual will come to support the organization, will concern himself/herself with its problems, will variably present it to others, and will try to aid it.” They proposed that organizations can accrue three specific benefits from board linkages: advice and consultancy, legitimacy and communication channels, as well as preferential treatment and support. These benefits are derived from the human capital (e.g. expertise, skills and knowledge) and relational capital of outside directors (Hillman \& Dalziel, 2003). Thus, having more outside directors would have a positive signalling effect 
which would enhance export propensity and export performance by stimulating an increase in their firms' legitimacy among their shareholders, providing resources through their social networks and decreasing export-related environmental uncertainty. As a consequence, it leads to the initiating of exporting and / or increased export sales (Fama \& Jensen, 1983; Rivas, 2012a, 2012b; Sanders \& Carpenter, 1998).

Moreover, based on the RDT, outside directors have a variety of viewpoints on analyzing the environment, stemming from their experience and social networks, and thus they are able to offer insightful and helpful solutions to resolve business problems (Bethel \& Rindova, 1994). According to Pearce and Zahra (1992), having more outside directors brings more strategic change than a board of directors dominated by insiders. Outside directors can provide valuable information and advice/counsel to the CEOs, as proposed by RDT theorists (Hillman, Withers, \& Collins, 2009). For instance, financial resources such as trade finance and trade insurance play crucial roles for exporters in starting exporting and in boosting export performance (Sherman, Kashlak, \& Joshi, 1998). Drawing on the RDT, Sanders and Carpenter (1998) explain that when a firm has more outside directors, it implies an advantage in terms of internationalization because of efficient governance arrangements which enable them to manage complexities according to the internationalization process. Consequently, we expect that when a firm hires a higher percentage of external board directors within the total number of board directors, these outside board directors may be more extensively networked and have a greater reputation as well as international knowledge. Thus, they not only enable their firm to be more effective in the acquisition of information needed for export decisions, but also bring in international knowledge that contributes to successful exporting. $\mathrm{Lu}, \mathrm{Xu}$, and Liu (2009) show that increasing the number and role of outside directors' helps to increase both export propensity and export performance using Chinese sample data. 
Regarding the Korean context, the Asian financial crisis 1997-1998 was a turning point in the development of the board system in Korea (Joh, 2003). In return for providing relief loans, the IMF demanded broad reforms across the Korean economy to enhance the vulnerable Korean corporate governance system (Joh, 2003). As a result, the Korean government has tightened up on outside director-related laws by requiring that outside directors should account for more than 25 per cent of board members (Choi, Park, \& Yoo, 2007). Thus, it is timely to explore the relationships among board directors as well as export propensity and export performance. We expect that a firm with a higher proportion of outside directors will achieve better export propensity and export performance than those with a lower proportion of outsiders on their boards. Based on the discussion above, we propose that:

Hypothesis 3a: A Korean firm's export propensity is positively associated with the proportion of outside directors.

Hypothesis 3b: A Korean firm's export performance is positively associated with the proportion of outside directors.

\section{Research Design}

\subsection{Sample and data}

We collected data from all the 642 non-financial listed firms in Korea over a seven-year period from 2001 to 2007. There are two reasons for choosing 2001 as the initial year of analysis. First, though the Korean government's official records include firms' annual reports from 1999, a substantial amount of information was missing in the early available years. Second, our main research purpose is to examine the board members as resource providers in 
the context of corporate governance reform. We, therefore, used annual reports beginning in 2001. Financial firms were excluded from our sample because their accounting structure differs from that of non-financial firms (Chizema et al., 2015). A few steps were taken to clean the data. First, we decided to use the same fiscal year for the sample firms in order to establish year dummy variables, so we excluded 27 firms with a different fiscal year to circumvent the confounding effects. Second, 65 firms did not provide relevant information. Third, 34 firms were dropped as they were spin-off firms which happened during the observation period due to the increase in radical financial transactions, such as increasing insider-trading profit (Brockman, Li, \& Price, 2013). As a result, our final sample consists of 516 (=642-27-65-34) firms.

Our data were drawn from the Korea Information Service (KIS). The KIS is analogous to COMPUSTAT from Standard \& Poor's (Chang \& Hong, 2002) and it provides reliable corporate and financial information. Similar data have been employed by a number of researchers (e.g. Chang \& Hong, 2002; Chang \& Rhee, 2011; Joh, 2003). Moreover, we also collected board information from the Data Analysis, Retrieval and Transfer system (DART) from the Financial Supervisory Service (FSS) of Korea.

\subsection{Dependent, independent and control variables}

In this subsection, we introduce the variables used in this study, and Table 1 defines these variables in detail. Following the existing studies (Fernández, \& Nieto, 2006; Gao et al., 2010), we used two dependent variables, export propensity (labelled EPR) and export performance (labelled EP). The former indicates whether a firm is exporting or not and reflects the firm's intent of expanding to overseas markets (Filatotchev et al., 2009). The latter measured export intensity which was captured by the ratio of export sales to total sales. These two measures are widely used as indicators for export propensity (whether to export) 
and export performance (how much to export) (Buck, et al., 2007; Lu, Xu, \& Liu, 2009). In the data analysis, we classify the sample firms into two categories: exporters and nonexporters. If a firm has export revenues in excess of 0 won, we regard the firm as an exporter. Conversely, if a firm reported 0 won in export revenues, it is a non-exporter.

\section{Insert Table 1 about here}

To capture the effectiveness of board directors with former official experience (labelled OFFICIAL) and MNC experience (labelled $M N C$ ), we created two dummy variables to measure board directors' past official experience and MNC experience. There are two reasons why we used the dummy variables. As aforementioned, MNCs have actively operated in Korea since the Asian financial crisis and local Koreans have had opportunities to work for MNCs. Therefore, there are a small number of board directors (8\%) who have had MNC work experience. Following existing studies (Hermalin \& Weisbach, 2003; Stiles, 2001), we considered board directors a team in order to examine the board directors' resource provider role. Although a board functions as a group (Hermalin \& Weisbach, 2003; Stiles, 2001), Forbes and Milliken (1999) and Payne, Benson, and Finegold (2009) stress that only a limited number of studies treat boards as a team. We used the proportion of outside directors (labelled OUTSIDE) to assess the extent of the outside directors' resource provider role (Payne, Benson, \& Finegold, 2009; Kim, 2007).

We included nine control variables based on previous research on the determinants of export performance. We controlled for firm size (labelled as SIZE) because it affects a firm's export behaviors (Gao et al., 2010). We controlled for board size (labelled BOARD) because it may affect a firm’s internationalization (Sanders \& Carpenter, 1998). A firm’s technology and marketing capabilities were controlled to capture the impact of intangible assets on exporting (Chang \& Hong, 2000). As Chang and Rhee (2011) note, chaebols may have a 
greater advantage in overseas sales than non-chaebols because they have a plurality of foreign subsidiaries to aid effectively the development of new customers and maintain current clients. Thus, we controlled for Korean business groups, chaebols (labelled CHAEBOLS). The leverage ratio (labelled LEVERAGE) is controlled as an important indicator of Korean firms’ capacity for international expansion, given that Korean firms depend on debt financing for their internationalization efforts (Chang, 2003). We controlled for the sample firms' past financial performance (labelled ROIC) (Chang \& Hong, 2000; 2002) to capture the impact of past financial performance on a firm’s decision concerning export activities (Hortinha, Lages, \& Lages, 2011; Lant, Milliken, \& Batra, 1992).

Finally, following the Korean Standard Industrial Classification (KSIC), industry dummies (labelled IND) and year dummies (labelled YED) are constructed to control for economy-wide, year-specific shocks and time-invariant firm heterogeneity. Industry dummies were used to establish fixed effects in the Heckman two-stage model. Technically, there is no clear-cut agreement regarding whether to estimate fixed effects or random effects to control for firm heterogeneity in the Heckman model. In order to remedy this issue, we used industry dummies and year dummies to establish panel data by controlling for firm heterogeneity and estimating causality because it is difficult to establish each firm's interaction terms in regressions (Hsiao, 1986). This is the main reason that we used industry dummy variables instead of firm dummy variables to estimate fixed effects.

\section{Empirical Results}

Table 2 reports descriptive statistics and correlations. It indicates that the highest value of the variance inflation factors (VIFs) is 1.19. Therefore, multicollinearity is not a serious problem in this study. In our sample, $48.2 \%$ of former officials had been heavily involved the 
industry and trade policies and had executed these policies strategically in their previous posts. Specifically, 33.41\% of former officials had worked for the Ministry of Strategy and Finance, and $14.79 \%$ of former officials had served in the Ministry of Trade, Industry and Energy.

\section{Ins_ert Tab}

\subsection{Heckman two-stage model}

While some firms export, others do not. Thus, our dependent variables are binary (exporting firm=1, non-exporting firm=0) based on a firm's export strategy choice, and this implies that our study may suffer from self-selection bias (Shaver, 1998). To address this issue, we apply the Heckman two-stage model. The Heckman (1979) two-stage model is more flexible and accurate than the Tobit model because it accounts for sample selection bias and uses two different parameters for the main equations of export propensity and export performance, respectively, while the Tobit model uses a single slope for both equations and does not consider the endogeneity issue.

Heckman's (1979) two-stage model involves the two-stage estimation. In the first stage, export propensity is estimated through the Probit analysis, and the IMR was extracted and used to estimate the probability values in the Probit regression. Then, in the second stage, export performance or export intensity is estimated through a truncated regression analysis including the IMR as one of the independent variables. To link the first stage and second stage, an estimated value for the IMR, denoted lambda or the hazard rate, is used to correct for selection bias (Heckman, 1979). In this study, we established a selection equation to take account of whether a company was exporting or not for measuring export propensity. We 
coded $\mathrm{EXPO}=1$ for an exporting firm and $\mathrm{EXPO}=0$ for a non-exporting firm in the binary dependent variable. Thus, the selection equation regarding EPR is defined as follows:

$$
\begin{aligned}
E P R_{i t}=\alpha_{1} \text { OFFICIAL }_{i t}+\alpha_{2} \text { MNC }_{i t}+\alpha_{3} \text { OUTSIDE }_{i t}+\alpha_{4} \text { SIZE }_{i t} \\
+\alpha_{5} \text { BOARD }_{i t}+\alpha_{6} \text { MKT }_{i t}+\alpha_{7} \text { TECH }_{i t}+\alpha_{8} \text { CHAEBOLS }_{i t} \\
+\alpha_{9} \text { LEVERAGE }_{i t}+\alpha_{10} \text { ROIC }_{i t}+\alpha_{11} X_{\mathrm{it}}+\varepsilon_{i t}
\end{aligned}
$$

Then, we estimated the main equation with EP as the dependent variable.

$$
\begin{gathered}
E P_{i t}=\beta_{1} \text { OFFICIAL }_{i t}+\beta_{2} \text { MNC }_{i t}+\beta_{3} \text { OUTSIDE }_{i t}+\beta_{4} \text { SIZE }_{i t}+\beta_{5} \text { BOARD }_{i t} \\
+\beta_{6} \text { MKT }_{i t}+\beta_{7} \text { TECH }_{i t}+\beta_{8} \text { CHAEBOLS }_{i t}+\beta_{9} L E V E R A G E_{i t} \\
+\beta_{10} \text { ROIC }_{i t}+\beta_{11} I M R_{i t}+\beta_{12} X_{t}+\varepsilon_{i t} \\
\text { for } \mathrm{i}=1,2, \ldots, \mathrm{n} \text { and } \mathrm{t}=1,2 \ldots, \mathrm{T} .
\end{gathered}
$$

In equations (1) and (2), the main variables of interest in this study are OFFICIAL, MNC, and OUTSIDE as we defined above. We also include SIZE, BOARD, MKT, TECH, CHAEBOLS, LEVERAGE, and ROIC as control variables that may affect a firm's EPR and EP. $X$ is a set of YED and 14 IND variables.

Inssert Table 2 2_about

We report the main results from testing the hypotheses in Tables 2 and 3 with respect to both $E P R$ and $E P$. Endogeneity is not a major concern here because the IMR is significant in the models for both EPR and EP (Tucker, 2010). These results suggest that Heckman's (1979) two-stage approach is appropriate for this study.

Hypotheses 1, 2, and 3 examine whether the board of directors plays a critical role in providing important resources for Korean firms by testing their effect on a firm's EPR and $E P$. The variable of OFFICIAL is positively and significantly associated with $E P R$ in model 4 
in Table 2. However, there is an insignificant relationship between this variable and EP in model 4 in Table 3. Thus, hypothesis 1(a) is supported, but hypothesis 1(b) is not.

\section{Inssert Tabble $\underline{3}$ _ here.}

Tables 3 and 4 respectively report the results of the impact of $M N C$ on $E P R$ and $E P$. The results from testing hypotheses 2(a) and 2(b) are consistent with our hypotheses and indicate that $M N C$ has a significant and positive association with both EPR and EP. Thus, hypotheses 2(a) and 2(b) are supported.

\section{Ins_ert _Table 4herere}

The variable of OUTSIDE is positively and significantly related to both EPR and EP in Tables 3 and 4 respectively. Therefore, hypotheses 3(a) and 3(b), which test whether there is a positive association between OUTSIDE (directors) and Korean firms' EPR and EP, are also supported.

\subsection{Additional analyses}

To complement the Heckman two-stage model, we conducted additional analyses using the quantile regression method to deal with causality issues by further assessing the impact of a board with government and MNC experience, and the proportion of outside directors, on a firm's export propensity and export performance. The quantile regression method was introduced by Koenker and Bassett (1978) and is widely used in IB and management research (Gallego-Álvarez \& Ortas, 2017; Paniagua, Figueiredo, \& Sapena, 2015; Ramdani \& Witteloostuijn, 2010). A simple linear regression method uses the conditional means of the variables, and thus crucial data characteristics may not be visible when the distribution of the dependent variable in the regression shows significant heterogeneity and non-normality (Coad \& Rao, 2006). In contrast, the quantile regression offers more flexible and more robust 
estimates than the mean regression, thus making it possible to better capture the response of the dependent variable by indicating how each independent variable affects the dependent variable (Gallego-Álvarez \& Ortas, 2017; Koenker \& Bassett, 1978; Ramdani \& Witteloostuijn, 2010). Technically, the quantile regression method does not apply to binary dependent variables, and thus we conduct this test on EP as the dependent variable.

In order to estimate several quantile regressions simultaneously, we examine and construct confidence intervals to compare the coefficients between quantiles. Within this estimation method, we consider the following simultaneous conditional quantile models using with the same measurements as we constructed for the Heckman sample selection model:

$$
\begin{aligned}
E P_{\mathrm{it}}= & \alpha+\beta_{1} \text { OFFICIAL }_{i t}+\beta_{2} M N C_{i t}+\beta_{3} \text { OUTSIDE }_{\mathrm{it}}+\sum_{\mathrm{j}} \delta_{j} X_{j, i t} \\
& +\sum_{\mathrm{t}} \lambda_{t} Y E D_{\mathrm{t}}+\theta I N D_{i}+\varepsilon_{\mathrm{it}}
\end{aligned}
$$

In Eq. (3), the coefficient $\beta$ indicates how EP is influenced by the three independent variables. In the set of other covariates ( $X$ ) that may affect a firm's $E P$, we include SIZE, BOARD, MKT, TECH, CHAEBOLS, LEVERAGE, and ROIC. Lastly, we also control for YED and IND.

\section{Insert Table 5 h here}

In Table 5, we report nine different quantiles from the 10th to the 90th quantiles which were used to gauge the different impacts of the three independent variables at different levels of distribution of EP. The results indicate that most of the signs of the coefficients regarding the three independent variables are in line with our predictions in Models 9 to 11. 


\section{Ins_ert Figure 1 1 herere}

One advantage of simultaneous quantile regressions is that we can see the dynamics in our main interested variables. We used the Lowess method to plot graphs (Cleveland, 1979). Figure 1 shows OFFICIAL coefficients estimated using the simultaneous quantile regression. Most quantiles are statistically insignificant except $40^{\text {th }}$ and $90^{\text {th }}$ quantiles. However, if we focus on the sign of the pattern of coefficients, OFFICIAL positively influences EP. The positive effect is steadily increased from $10^{\text {th }}$ to $90^{\text {th }}$ quantiles.

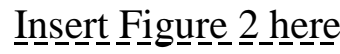

Figure 2 illustrates that $M N C$ exhibits a positive impact on EP in every quantile (from the $20^{\text {th }}$ to $90^{\text {th }}$ quantiles being statistically significant). The positive impact of $M N C$ is increased until the $50^{\text {th }}$ quantile of $E P$. This implies that firms with higher $E P$ respond more to the MNC variable, but this positive impact does not change substantially when moving beyond the $50^{\text {th }}$ quantile of $E P$ distribution.

\section{Ins_ert Figure}

Lastly, Figure 3 indicates that OUTSIDE also has a positive effect on EP in every quantile: seven out of nine quantiles are statistically significant. Notably, OUTSIDE exhibits a more positive effect from the lower to the upper tail of the distribution of EP. Taken together, the results of the quantile regressions are consistent with our main findings, thus further confirming that the main results do not suffer from reverse causality.

\section{Discussion}

7.1 The main findings 
Adopting the resource dependency perspective, we examine the impact of the resource provision role of board members on export propensity and export performance for a sample of Korean firms. More specifically, we empirically test the relationship between board members with previous government experience and board members with MNC experience, as well as the proportion of outside directors, and the export propensity and export performance of Korean firms. We have additionally investigated the impact of these main variables on a firm's export performance using the simultaneous quantile regression method. As explained above, we conducted our investigation in the Korean context and accounted for some specific institutional characteristics of this context under which the composition of the board affects exporting.

We have obtained a number of interesting findings. First, the presence of a board member with government experience represents a relatively distinct aspect of the Korean culture which has received little attention so far. We found empirical support for former officials having a positive effect on export propensity. This may suggest that a former official is effective in initiating a firm's export activities, perhaps due to their ability to extract essential export-related resources from outside the firm. Board directors with government experience may influence government-related banks or state-owned institutions facilitating export financing and, thus, enhance a firm's export propensity in the Korean context based on 'gosi' and 'jeongwan yeu' cultures. Contrary to our expectations, former officials do not have a positive effect on export performance. The quantile regression results are also in line with our main analysis based on the Heckman model: most quantiles exhibit as statistically insignificant. Thus, it further confirms our main result that board directors with former official experienced do not affect Korean firms' export performance. This finding may suggest that when firms expand internationally, they face challenges in translating the 
advantages associated with government experience or political connections into export performance. The advantages associated with political connections are not universal, but context specific. This may be the reason why board members with formal government experience have little impact on export performance in international markets.

Second, we confirm that the MNC experience of board members is positively associated with both export propensity and export performance. The findings complement the prior literature which has overlooked the impact of MNC experience on firm internationalization in the Korean context (Chizema \& Kim, 2010; Cho \& Kim, 2007). Since the Asian financial crisis, more Korean workers have had an opportunity to work for MNCs, through which they learn best practices and develop networks (Chang, 2006). Board members with MNC experience may be effective in facilitating exporting due to their international experience and their understanding of how to initiate, operate and develop exporting activities, given that most of the MNCs operating in Korea have developed a long history and good track record in international business relative to local Korean companies. In this regard, board members with MNC experience may have accumulated both human and social capital and thus serve not only as resource providers to facilitate exporting by exploiting their social networks, but also act as important sources of human capital.

The results based on the quantile regression are consistent with those obtained from the Heckman model, thus further supporting our arguments that boards with MNC experience facilitate the identification of overseas business opportunities (McDougall, Oviatt, \& Shrader, 2003) and act as a good channel to bring in crucial external resources (Filatotchev et al., 2009), especially for small and medium-sized Korean exporting firms.

Finally, we test whether outside directors play an important role in enhancing Korean firms' export propensity and export performance. We find that the presence of outside 
directors improves both the export propensity and export performance of the sample firms. It is worth examining the role of outside directors as the outside director system originated from the system of Anglo-American governance, and was introduced in Korea in the wake of the Asian financial crisis. Our finding supports the notion that outside directors have the ability to contribute additional resources to enhance the export sales of Korean firms (Kim, 2005). As shown in our additional analyses, a firm having more outside directors leads to an increase in export performance from $10^{\text {th }}$ to $90^{\text {th }}$ quantiles. As quantiles go up, the coefficient of the variable of outside directors is increased. In other words, firms with more outside directors exhibit higher levels of exports. One plausible explanation for these findings might be due to corporate governance reforms in Korea, such as appointing outside directors in the aftermath of the 1997-1998 financial crisis. Outside directors bring more external resources to boost their firms' exporting. The findings support not only our main results more vividly, but also confirm again the resource provision role of board members in their firms' internationalization, underpinned by RDT.

Taken together, a Korean board is more likely to contribute to export propensity when its members include former government officials and those with MNC work experience, as well as outside directors. The latter two types of board members (with MNC work experience, and outsider directors) also positively affect the export performance of their firms. Our findings thus provide a more complete picture regarding the resource provision role of board members in exporting in the Korean context.

\subsection{Contributions}

This study contributes to the fields of IB and corporate governance in a number of ways. First, by exploring the impact of board members' specific characteristics on Korean firms' 
export propensity and export performance, this research complements prior research by emphasizing the resource provision role of board directors in exporting. Previous studies on export performance have tended to focus on internal capability, industry competition and institutional environments (Buck, et al., 2007; Chen, Sousa, \& He, 2016; Gao, et al., 2010), but have paid little attention to the impact of board directors with government experience and MNE experience on exporting.

One the other hand, extent research on corporate governance has overly focused on the monitoring role of board directors underpinned by the dominant paradigm of agency theory (Hillman, Cannella, \& Paetzold, 2000; Rivas, 2012a; Sanders \& Carpenter, 1998). Such a focus overlooks the resource provision role of board directors. We move beyond the existing studies and unpack the link between board directors and firms' export propensity and export performance. The findings enhance our understanding of the determinants of export propensity and export performance by revealing different dimensions of board directors from a resource dependency perspective. Relatedly, by explicitly focusing on export activities, our study enriches prior research by moving away from financial performance and firm value to consideration of other type of organizational outcomes, such as export performance. This helps to provide a more complete account of the impact of board directors on their organizations.

Second, this study expands the resource dependency perspective to a unique institutional context where the government and businesses are closely intertwined. Our research demonstrates that the country-specific institutional setting is important in understanding the impact of board directors. There is a unique culture called 'jeongwan yeu' regarding former officials in Korea. After retirement, they move to companies or law firms as lobbyists. This research sheds light on how the background of board members as former 
government officials can affect a firm's export propensity in an institutional context with strong government intervention based on 'jeongwan yeu'. In addition, a number of Korean firms recruit board members with MNC experience in order to compete with foreign MNCs that have entered the Korean market. Third, after the 1997-1998 Asian financial crisis, the Korean government enacted a law that Korean firms must have at least $25 \%$ of total board members made up of outside board members. The impact of these corporate governance changes on outside directors has been underexplored (Cho \& Kim, 2007; Kim, 2007), especially with regard to Korean firms' export propensity and export performance. Hence, our research provides new insight into the benefit of political connections, MNC experience and outside directors in exporting, and captures elements of power and dependency in the Korean context.

Finally, we not only controlled for endogeneity by estimating the Heckman two-stage model with firm-level fixed effects, but also controlled for causality issues using the simultaneous quantile regression. We thus add much needed empirical evidence to the relationship between the characteristics of board directors and the first step of internationalization by firms in an emerging economy.

\subsection{Policy and managerial implications}

This research has several implications for policy makers and managers. As board members, former officials can improve their firms' export propensity. Thus, if a firm is eager to export, it would benefit from hiring former officials as board members to access crucial external resources. When firms expand internationally, they face challenges in translating the advantages associated with government experience or political connections into export performance. This may imply that the adverse selection problem will generate a high social 
cost if firms with a low capacity, limited R\&D and product development capabilities engage in exporting based on their directors' political ties.

It is also especially important for export-oriented firms to have qualified board members with MNC experience because their international knowledge and social capital are beneficial in initiating and increasing export sales. Our findings suggest that firms need to consider the characteristics of board directors in establishing a human resource strategy to effectively recruit and retain the talent they need to improve their export propensity and export performance. Finally, this study empirically confirms that the more outside directors a firm has, the better its export propensity and export performance will be. The result implies that firms with a tendency to appoint outside directors who are able to provide external resources will prove to be more successful in enhancing export propensity and export performance. Our findings also provide empirical evidence that supports the government-led reform to introduce the outside-director system, which is beneficial to firm internationalization.

\subsection{Limitations and directions for future research}

Our study has a number of limitations that indicate the need for future research. First, it is difficult to measure the quality of each board member. For instance, there are MNCs such as Coca-Cola and P\&G that represent leading firms in their respective industries. MNC experience may be heterogeneous. To address this issue, it may be beneficial to combine information using survey and qualitative methods. Related, while we have adopted a commonly used measure for outside directors, we are unable to measure the background and quality of individual outside directors due to data availability. Future studies should use a more fine-grained proxy to accurately capture the resource provision role of outside directors with different skills and knowledge. 
Second, our research is based on a sample of Korean firms. The results may not be generalizable to firms in other countries. Future research is needed to compare our results with those from other countries using firm-level data, or to extend our research to other emerging economies.

Third, we attempted to collect information on board members to compare the results before and after the reform of the corporate governance system in Korea. The Korean government, however, only provided such information for the period after the implementation of the outside-director policy. It would be a valuable research avenue to compare firm export propensity and export performance before and after the corporate governance reform in Korea over a longer period, once data are available.

Fourth, we measured former government experiences and the MNC experience of the board directors as dummy variables. Therefore, further research could use more fine-grained measures to capture the impact of the characteristics of board directors on firm internationalization. Furthermore, it may be meaningful to examine the relationships between interlocking directorate networks and internationalization performance. The Korean annual reports, however, provide very limited board information enabling researchers to examine political ties between board directors and main politicians, such as president and head of ministers. Thus, researchers should find alternative methodologies, or a different data set, to measure these relationships in future research.

Fifth, while we have made a great effort to tackle causality issues by adopting the Heckman sample selection model and simultaneous quantile regression, we cannot claim that our findings are free from the causality issue. It is generally recognized that it is difficult to perfectly control for causality issues. In this regard, our research also contains this commonly acknowledged limitation. Future research should use various methodologies such as a case 
study or survey method to verify our findings. Lastly, future research could examine the role of the board of directors as resource providers, and the composition of the board beyond the first step of internationalization, such as foreign direct investment and cross-border mergers and acquisitions.

\section{Conclusion}

This study represents an extension of prior IB and corporate governance research by exploring the effect of the resource provider role of boards on firm export propensity and export performance, given that this aspect has received little attention from scholars. Drawing on RDT, we focused on examining the extent to which board members with former official experience, and those with MNC backgrounds, as well as the proportion of outside directors overall, affect the first step of internationalization, based on a sample of Korean firms.

We have obtained a number of interesting results. First, there is empirical support for former officials having a positive effect on export propensity through their capacity to provide resources to enhance export activities. There is, however, no empirical evidence supporting export performance. Second, we confirmed that MNC experience is positively associated with both export propensity and export performance. Finally, the proportion of outside directors is positively associated with export propensity and export performance. This study moves beyond existing studies on the monitoring role of the board of directors and sheds new light on the resource provision role of board members in exporting.

\section{References}

Anti-Corruption \& Civil Rights Commission of Korea. (2012). The anti-corruption policy of Korea and efforts to enhance integrity. Retrieved from http://www.acrc.go.kr/eng/file/file.do?command=downFile\&encodedKey=MTgxNDRfM Q\%3D\%3D. Accessed 5 June 2017. 
Athanassiou, N., and Nigh, D. (2002). The impact of the top management team's international business experience on the firm's internationalization: Social networks at work. Management International Review, 42(2), 157-181.

Bae, J., Chen, S. J., David Wan, T. W., Lawler, J. J., \& Walumbwa, F. O. (2003). Human resource strategy and firm performance in Pacific rim countries. The International Journal of Human Resource Management, 14(8), 1308-1332.

Baek, J. S., Kang, J. K., \& Park, K. S. (2004). Corporate governance and firm value: Evidence from the Korean financial crisis. Journal of Financial Economics, 71(2), 265313.

Barroso, C., Villegas, M. M., \& Pérez - Calero, L. (2011). Board influence on a firm's internationalization. Corporate Governance: An International Review, 19(4), 351-367.

Bethel, J., \& Rindova, V. (1994). The impact of CEO, top management teams, and boards of directors turnover on corporate restructuring. Proceedings of The Second International Federation of Scholarly Associations in Management, Dallas, Texas.

Boyd, B. (1990). Corporate linkages and organizational environment: A test of the resource dependence model. Strategic Management Journal, 11(6), 419-430.

Brockman, P., Li, X., \& Price, S. M. (2013). Do managers put their money where their mouths are? Evidence from insider trading after conference calls. Social Science Research Network Working Paper Series.

Buck, T., Liu, X., \& Skovoroda, R. (2008). Top executive pay and firm performance in China. Journal of International Business Studies, 39(5), 833-850.

Buck, T., Liu, X., Wei, Y., \& Liu, X. (2007). The trade development path and export spillovers in China: A missing link?. Management International Review, 47(5), 683-706.

Chang, S. J. (2003). Ownership structure, expropriation, and performance of group-affiliated companies in Korea. Academy of Management Journal, 46(2), 238-253.

Chang, S. J. (2006). Business groups in East Asia: Post-crisis restructuring and new growth. Asia Pacific Journal of Management, 23(4), 407-417.

Chang, S. J., \& Choi, U. (1988). Strategy, structure and performance of Korean business groups: A transactions cost approach. The Journal of Industrial Economics, 37(2), 141158.

Chang, S. J., \& Hong, J. (2000). Economic performance of group-affiliated companies in Korea: Intragroup resource sharing and internal business transactions. Academy of Management Journal, 43(3), 429-448.

Chang, S. J., \& Hong, J. (2002). How much does the business group matter in Korea?. Strategic Management Journal, 23(3), 265-274.

Chang, S. J., \& Rhee, J. H. (2011). Rapid FDI expansion and firm performance. Journal of International Business Studies, 42(8), 979-994.

Chen, J., Sousa, C. M. P. \& He, X. (2016). The determinants of export performance: A review of the literature 2006-2014. International Marketing Review, 33(5), 626-670.

Chizema, A., \& Kim, J. (2010). Outside directors on Korean boards: Governance and institutions. Journal of Management Studies, 47(1), 109-129.

Chizema, A., Liu, X., Lu, J., \& Gao, L. (2015). Politically connected boards and top executive pay in Chinese listed firms. Strategic Management Journal, 36(6), 890-906.

Cho, D. S., \& Kim, J. (2007). Outside directors, ownership structure and firm profitability in Korea. Corporate Governance: An International Review, 15(2), 239-250.

Choi, J. J., Park, S. W., \& Yoo, S. S. (2007). The value of outside directors: Evidence from corporate governance reform in Korea. Journal of Financial and Quantitative Analysis, 42(4), 941-962. 
Clarke, T. (2017). International corporate governance: A comparative approach. $2^{\text {nd }}$ edition, Routledge.

Cleveland, W. S. (1979). Robust locally weighted regression and smoothing scatterplots. Journal of the American Statistical Association, 74(368), 829-836.

Coad, A., \& Rao, R. (2006). Innovation and market value: a quantile regression analysis. Economics Bulletin, 15(13), 1-10.

Czinkota, M. and Ronkainen, I. A. (2007), International Marketing, Florence, KY: Cengage Learning.

Daily, C. M., Certo, S. T., \& Dalton, D. R. (2000). International experience in the Executive suite: The Path to Prosperity? Strategic Management Journal, 21(4), 515-523.

Durand, R., \& Jourdan, J. (2012). Jules or Jim: Alternative conformity to minority logics. Academy of Management Journal, 55(6), 1295-1315.

Eriksson, K., Johanson, J., Majkgard, A., \& Sharma, D. D. (1997). Experiential knowledge and cost in the internationalization process. Journal of International Business Studies, 28(2), 337-360.

Fama, E. F., \& Jensen, M. C. (1983). Separation of ownership and control. Journal of Law and Economics, 26(2), 301-325.

Fernández, Z. \& Nieto, M. J. (2006). Impact of ownership on the international involvement of SMEs, Journal of International Business Studies, 37(3), 340-351.

Filatotchev, I., Liu, X., Buck, T., \& Wright, M. (2009). The Export orientation and export performance of high-technology SMEs in emerging markets: The effects of knowledge transfer by returnee entrepreneurs. Journal of International Business Studies, 40(6), 1005-1021.

Forbes, D. P., \& Milliken, F. J. (1999). Cognition and corporate governance: Understanding boards of directors as strategic decision-making groups. Academy of Management Review, 24(3), 489-505.

Gallego-Álvarez, I., \& Ortas, E. (2017). Corporate environmental sustainability reporting in the context of national cultures: A quantile regression approach. International Business Review, 26(2), 337-353.

Gao, G. Y., Murray, J. Y., Kotabe, M., \& Lu, J. (2010). A “Strategy Tripod” perspective on export behaviors: Evidence from domestic and foreign firms based in an emerging economy. Journal of International Business Studies, 41(3), 377-396.

Garud, R., Jain, S. \& Kumaraswamy, A. (2002). Institutional entrepreneurship in the sponsorship of common technological standards: The case of Sun Microsystems and Java. Academy of Management Journal, 45(1), 196-214.

George, G., Wiklund, J., \& Zahra, S. A. (2005). Ownership and the internationalization of small firms. Journal of Management, 31(2), 210-233.

Ghoshal, S., \& Bartlett, C. A. (1990). The multinational corporation as an interorganizational network. Academy of Management Review, 15(4), 603-626.

Gulati, R. (1995). Does familiarity breed trust? The implications of repeated ties for contractual choice in alliances. Academy of Management Journal, 38(1), 85-112.

Ha, Y. C., \& Kang, M. K. (2010). Creating a capable bureaucracy with loyalists: The internal dynamics of the South Korean developmental state, 1948-1979. Comparative Political Studies, 44(1), 78-108.

Heckman, J. J. (1979). Sample selection bias as a specification error. Econometrica, 47(1), 153-161. 
Hermalin, B. E., \& Weisbach, M.S. (2003). Boards of directors as an endogenously determined institution: A survey of the economic literature (No. w8161). National Bureau of Economic Research.

Herrera-Echeverri, H., Geleilate, J. G., Gaitan-Riaño, S., Haar, J., \& Soto-Echeverry, N. (2016). Export behavior and board independence in Colombian family firms: The reverse causality relationship. Journal of Business Research, 69(6), 2018-2029.

Hillman, A. J. (2005). Politicians on the board of directors: Do connections affect the bottom line?. Journal of Management, 31(3), 464-481.

Hillman, A. J., \& Dalziel, T. (2003). Boards of directors and firm performance: Integrating agency and resource dependence perspectives. Academy of Management Review, 28(3), 383-396.

Hillman, A. J., \& Hitt, M. A. (1999). Corporate political strategy formulation: A model of approach, participation, and strategy decisions. Academy of Management Review, 24(4), 825-842.

Hillman, A. J., Cannella, A. A., \& Paetzold, R. L. (2000). The resource dependence role of corporate directors: Strategic adaptation of board composition in response to environmental change. Journal of Management Studies, 37(2), 235-256.

Hillman, A. J., Withers, M. C., \& Collins, B. J. (2009). Resource dependence theory: A review. Journal of Management, 35(6), 1404-1427.

Hortinha, P., Lages, C., \& Lages, F. L. (2011). The trade-off between customer and technology orientations: Impact on innovation capabilities and export performance. Journal of International Marketing, 19(3), 36-58.

Hsiao, C. (1986). Analysis of panel data. NY: Cambridge University Press.

Iriyama, A., \& Madhavan, R. (2014). Post-Formation Inter-Partner Equity Transfers in International Joint Ventures: The Role of Experience. Global Strategy Journal, 4(4), 331-348.

Joh, S.W. (2003). Corporate governance and firm profitability: Evidence from Korea before the economic crisis. Journal of Financial Economics, 68(2), 287-322.

Johnson, J. L., Daily, C. M., \& Ellstrand, A. E. (1996). Boards of directors: A review and research agenda. Journal of Management, 22(3), 409-438.

Kim, D. O., \& Kim, S. (2003). Globalization, financial crisis, and industrial relations: The case of South Korea. Industrial Relations: A Journal of Economy and Society, 42(3), 341-367.

Kim, D., \& Yu, G. C. (2000). Emerging patterns of human resource management in Korea: Evidence from large Korean firms. In 12th IIRA World Congress, Tokyo, Japan.

Kim, Y. (2005). Board network characteristics and firm performance in Korea. Corporate Governance: An International Review, 13(6), 800-808.

Kim, Y. (2007). The proportion and social capital of outside directors and their impacts on firm value: Evidence from Korea. Corporate Governance: An International Review, 15(6), 1168-1176.

Koenker, R., \& Bassett Jr, G. (1978). Regression quantiles. Econometrica, 46(1), 33-50.

Lant, T. K., Milliken, F. J., \& Batra, B. (1992). The role of managerial learning and interpretation in strategic persistence and reorientation: An empirical exploration. Strategic Management Journal, 13(8), 585-608.

Lee, J. Y., \& MacMillan, I. C. (2008). Managerial knowledge-sharing in chaebols and its impact on the performance of their foreign subsidiaries. International Business Review, 17(5), 533-545. 
Leonidou, L. C. (1995a). Empirical research on export barriers: Review, assessment, and synthesis. Journal of International Marketing, 3(1), 29-43.

Leonidou, L. Palihawadana, D., \& Theodosiou, M. (2011). National Export-Promotion Programs as Drivers of Organizational Resources. Journal of International Marketing, 19(2), 1-29.

Liu, Y., Wei, Z., \& Xie, F. (2014). Do women directors improve firm performance in China?. Journal of Corporate Finance, 28, 169-184.

Lu, J., Xu, B., \& Liu, X. (2009). The effects of corporate governance and institutional environments on export behaviour in emerging economies. Management International Review, 49(4), 455-478.

Luo, Y. (2005). How does globalization affect corporate governance and accountability? A perspective from MNEs. Journal of International Management, 11(1), 19-41.

Luo, Y., Xue, Q., \& Han, B. (2010). How emerging market governments promote outward FDI: Experience from China. Journal of World Business, 45(1), 68-79.

McDougall, P. P., Oviatt, B. M., \& Shrader, R. C. (2003). A comparison of international and domestic new ventures. Journal of International Entrepreneurship, 1(1), 59-82.

Miesenbock, K. J. (1988). Small businesses and exporting: A literature review. International Small Business Journal, 6(2), 42-61.

Ntim, C. G. (2015). Board diversity and organizational valuation: Unravelling the effects of ethnicity and gender. Journal of Management \& Governance, 19(1), 167-195.

Ntim, C. G., Lindop, S., \& Thomas, D. A. (2013). Corporate governance and risk reporting in South Africa: A study of corporate risk disclosures in the pre- and post-2007/2008 global financial crisis period. International Review of Financial Analysis, 30, 363-383.

Ntim, C. G., Lindop, S., Osei, K. A., \& Thomas, D. A. (2015). Executive compensation, corporate governance and corporate performance: A simultaneous equation approach. Managerial and Decision Economics, 36(2), 67-96.

Ntim, C. G., Opong, K. K., \& Danbolt, J. (2012a). Relative value relevance of shareholder versus stakeholder corporate governance disclosure policy reforms in South Africa. Corporate Governance: An International Review, 20(1), 84-105.

Ntim, C. G., Opong, K. K., \& Danbolt, J. (2015). Board size, corporate regulations and firm valuation in an emerging market: A simultaneous equation approach. International Review of Applied Economics, 29(2), 194-220.

Oliver, C. (1991). Strategic responses to institutional processes. Academy of Management Review, 16(1), 145-179.

Paniagua, J., Figueiredo, E., \& Sapena, J. (2015). Quantile regression for the FDI gravity equation. Journal of Business Research, 68(7), 1512-1518.

Park, S. H., \& Luo, Y. (2001). Guanxi and organizational dynamics: Organizational networking in Chinese firms. Strategic Management Journal, 22(5), 455-477.

Payne, G. T., Benson, G. S., \& Finegold, D. L. (2009). Corporate board attributes, team effectiveness and financial performance. Journal of Management Studies, 46(4), 704-731.

Pearce, J. A., \& Zahra, S. A. (1992). Board composition from a strategic contingency perspective. Journal of Management Studies, 29(4), 411-438.

Pfeffer, J., \& Salancik, G. R. (1978). The external control of organizations: A resource dependence Approach. NY: Harper and Row Publishers.

Ramdani, D., \& Witteloostuijn, A. V. (2010). The impact of board independence and CEO duality on firm performance: A quantile regression analysis for Indonesia, Malaysia, South Korea and Thailand. British Journal of Management, 21(3), 607-627. 
Rivas, J. L. (2012a). Co-opting the environment: An empirical test of resource-dependence theory. The International Journal of Human Resource Management, 23(2), 294-311.

Rivas, J. L. (2012b). Diversity \& internationalization: The case of boards and TMT's. International Business Review, 21(1), 1-12.

Rivas, J. L., Hamori, M., \& Mayo, M. (2009). Board composition and firm internationalization. In Academy of Management Proceedings (Vol. 2009, No. 1, pp. 1-6). Academy of Management.

Rodríguez, J. L., \& Rodríguez, R. M. G. (2005). Technology and export behaviour: A resource-based view approach. International Business Review, 14(5), 539-557.

Roth, K. (1995). Managing international interdependence: CEO characteristics in a resourcebased framework. Academy of Management Journal, 38(1), 200-231.

Sanders, W. G., \& Carpenter, M. A. (1998). Internationalization and Firm Governance: The Roles of CEO Compensation, Top team composition, and board structure. Academy of Management Journal, 41(2), 158-178.

Schuler, D. A., Rehbein, K., \& Cramer, R. D. (2002). Pursuing strategic advantage through political means: A multivariate approach. Academy of Management Journal, 45(4), 659672.

Shaver, J. M. (1998). Accounting for endogeneity when assessing strategy performance: Does entry mode choice affect FDI survival?. Management Science, 44(4), 571-585.

Sherman, H. D., Kashlak, R. J., \& Joshi, M. P. (1998). The effect of the board and executive committee characteristics on the degree of internationalization. Journal of International Management, 4(4), 311-335.

Siegel, J. (2007). Contingent political capital and international alliances: Evidence from South Korea. Administrative Science Quarterly, 52(4), 621-666.

Stiles, P. (2001). The impact of the board on strategy: An empirical examination. Journal of Management Studies, 38(5), 627-650.

Tayeb, M. (1998). Transfer of HRM practices across cultures: an American company in Scotland. International Journal of Human Resource Management, 9(2), 332-358.

Tesfom, G., Lutz, C., \& Ghauri, P. (2004). Comparing export marketing channels: Developed versus developing countries. International Marketing Review, 21(4/5), 409-422.

Tucker, J. W. (2010), Selection bias and econometric remedies in accounting and finance research. Journal of Accounting Literature, 29(1), 31-57.

Zhao, H., \& Zou, S. (2002). The impact of industry concentration and firm location on export propensity and intensity: An empirical analysis of Chinese manufacturing firms. Journal of International Marketing, 10(1), 52-71. 


\section{Table 1 Summary of variables}

Dependent variables

$E P R$

EP

Independent variables

OFFICIAL

$M N C$

OUTSIDE

Control variables

SIZE

BOARD

TECH

MKT

CHAEBOLS

LEVERAGE

ROIC

YED

IND
A dummy variable that takes value of 1 , if a firm is exporting, 0 otherwise

The ratio of export sales to the total sales

A dummy variable if a board member has any of former official experience

A dummy variable if a board member has any of MNC experience

The proportion of outside directors to the total number of board members

Natural log of total assets

The total number of board members

R\&D expenditures divided by total sales

Advertising expenditures divided by total sales

A dummy variable that takes the values of 1 if it belongs to chaebols, 0 otherwise

Total firm liabilities divided by total firm assets

The sum of net income before tax plus interest payments

(Net Operating Profit-Adjusted Taxes)/Invested Capital

Year dummies from 2001 to 2007 inclusive

Industry dummies for the 14 industries 
Table 2 Descriptive statistics and correlations

\begin{tabular}{|c|c|c|c|c|c|c|c|c|c|c|c|c|c|}
\hline & & 1 & 2 & 3 & 4 & 5 & 6 & 7 & 8 & 9 & 10 & 11 & 12 \\
\hline 1 & EP & 1.000 & & & & & & & & & & & \\
\hline 2 & EPR & 0.093 & 1.000 & & & & & & & & & & \\
\hline 3 & OFFICIAL & 0.018 & 0.078 & 1.000 & & & & & & & & & \\
\hline 4 & MNC & 0.050 & 0.100 & 0.120 & 1.000 & & & & & & & & \\
\hline 5 & OUTSIDE & 0.061 & 0.068 & 0.185 & 0.064 & 1.000 & & & & & & & \\
\hline 6 & SIZE & 0.053 & 0.174 & 0.238 & 0.206 & 0.284 & 1.000 & & & & & & \\
\hline 7 & BOARD & 0.041 & 0.026 & 0.035 & 0.063 & 0.054 & 0.080 & 1.000 & & & & & \\
\hline 8 & $\mathrm{MKT}$ & -0.041 & -0.029 & -0.042 & -0.024 & -0.037 & -0.008 & 0.046 & 1.000 & & & & \\
\hline 9 & TECH & 0.217 & 0.017 & 0.020 & 0.011 & -0.010 & 0.020 & -0.006 & 0.271 & 1.000 & & & \\
\hline 10 & CHAEBOLS & 0.022 & -0.044 & 0.121 & 0.077 & 0.285 & -0.068 & 0.162 & 0.044 & 0.033 & 1.000 & & \\
\hline 11 & LEVERAGE & -0.009 & -0.036 & 0.020 & -0.042 & 0.052 & -0.010 & 0.003 & -0.025 & -0.007 & 0.059 & 1.000 & \\
\hline 12 & ROIC & -0.007 & -0.060 & -0.017 & -0.009 & -0.018 & -0.034 & -0.027 & -0.013 & -0.007 & -0.008 & -0.045 & 1.000 \\
\hline & Mean & 0.319 & 0.706 & 0.215 & 0.076 & 0.322 & 26.208 & 5.824 & 0.009 & 0.016 & 0.204 & 0.470 & 22.346 \\
\hline & SD & 0.027 & 0.008 & 0.007 & 0.005 & 0.002 & 0.024 & 0.047 & 0.000 & 0.002 & 0.007 & 0.009 & 7.182 \\
\hline & VIF & 1.08 & 1.03 & 1.08 & 1.07 & 1.19 & 1.02 & 1.16 & 1.02 & 1.01 & 1.17 & 1.07 & 1.01 \\
\hline
\end{tabular}


Table 3 Factors affecting export propensity (EPR)

\begin{tabular}{|c|c|c|c|c|}
\hline \multirow[t]{2}{*}{ Variables } & \multicolumn{4}{|c|}{$E O$} \\
\hline & Model 1 & Model 2 & Model 3 & Model 4 \\
\hline INTERCEPT & $\begin{array}{l}-0.428^{*} \\
(0.507)\end{array}$ & $\begin{array}{l}-0.344 * \\
(0.509)\end{array}$ & $\begin{array}{l}-0.302 * \\
(0.512)\end{array}$ & $\begin{array}{l}-0.352^{*} \\
(0.514)\end{array}$ \\
\hline OFFICIAL & & $\begin{array}{l}2.191 * * \\
(0.073)\end{array}$ & $\begin{array}{l}0.196 * * * \\
(0.074)\end{array}$ & $\begin{array}{l}0.181^{* *} \\
(0.074)\end{array}$ \\
\hline$M N C$ & & & $\begin{array}{l}0.469 * * * \\
(0.133)\end{array}$ & $\begin{array}{l}0.467 * * * \\
(0.133)\end{array}$ \\
\hline OUTSIDE & & & & $\begin{array}{l}0.443^{*} \\
(0.255)\end{array}$ \\
\hline SIZE & $\begin{array}{l}-0.010 \\
(0.019)\end{array}$ & $\begin{array}{l}-0.012 \\
(0.019)\end{array}$ & $\begin{array}{l}-0.014 \\
(0.019)\end{array}$ & $\begin{array}{l}-0.015 \\
(0.019)\end{array}$ \\
\hline BOARD & $\begin{array}{l}0.060^{* * *} \\
(0.013)\end{array}$ & $\begin{array}{l}0.054^{* * *} \\
(0.013)\end{array}$ & $\begin{array}{l}0.047 * * * \\
(0.013)\end{array}$ & $\begin{array}{l}0.042^{* * *} \\
(0.013)\end{array}$ \\
\hline$M K T$ & $\begin{array}{l}-2.425 \\
(1.430)\end{array}$ & $\begin{array}{l}-2.051 \\
(1.443)\end{array}$ & $\begin{array}{l}-2.046 \\
(1.436)\end{array}$ & $\begin{array}{l}-1.989 \\
(1.443)\end{array}$ \\
\hline TECH & $\begin{array}{l}5.156^{* * *} \\
(1.296)\end{array}$ & $\begin{array}{l}5.041^{* * *} \\
(1.301)\end{array}$ & $\begin{array}{l}5.173^{* * *} \\
(1.316)\end{array}$ & $\begin{array}{l}4.970 * * * \\
(1.318)\end{array}$ \\
\hline CHAEBOLS & $\begin{array}{l}0.046 \\
(0.075)\end{array}$ & $\begin{array}{l}0.024 \\
(0.075)\end{array}$ & $\begin{array}{l}0.008 \\
(0.076)\end{array}$ & $\begin{array}{l}-0.024 \\
(0.078)\end{array}$ \\
\hline LEVERAGE & $\begin{array}{l}0.409 * * * \\
(0.144)\end{array}$ & $\begin{array}{l}0.375^{* * * *} \\
(0.144)\end{array}$ & $\begin{array}{l}0.426 * * * \\
(0.145)\end{array}$ & $\begin{array}{l}0.402^{* * *} \\
(0.146)\end{array}$ \\
\hline ROIC & $\begin{array}{l}-0.007^{* * * *} \\
(0.002)\end{array}$ & $\begin{array}{l}-0.007 * * * \\
(0.002)\end{array}$ & $\begin{array}{l}-0.008^{* * *} \\
(0.002)\end{array}$ & $\begin{array}{l}-0.007 * * * \\
(0.002)\end{array}$ \\
\hline YED02 & $\begin{array}{l}0.056 \\
(0.109)\end{array}$ & $\begin{array}{l}0.048 \\
(0.109)\end{array}$ & $\begin{array}{l}0.045 \\
(0.110)\end{array}$ & $\begin{array}{l}0.043 \\
(0.110)\end{array}$ \\
\hline YED03 & $\begin{array}{l}-0.001 \\
(0.108)\end{array}$ & $\begin{array}{l}-0.009 \\
(0.108)\end{array}$ & $\begin{array}{l}-0.014 \\
(0.108)\end{array}$ & $\begin{array}{l}-0.023 \\
(0.109)\end{array}$ \\
\hline YED04 & $\begin{array}{l}0.039 \\
(0.108)\end{array}$ & $\begin{array}{l}0.037 \\
(0.108)\end{array}$ & $\begin{array}{l}0.033 \\
(0.108)\end{array}$ & $\begin{array}{l}0.021 \\
(0.109)\end{array}$ \\
\hline YED05 & $\begin{array}{l}-0.000 \\
(0.106)\end{array}$ & $\begin{array}{l}-0.006 \\
(0.106)\end{array}$ & $\begin{array}{l}-0.013 \\
(0.107)\end{array}$ & $\begin{array}{l}-0.030 \\
(0.107)\end{array}$ \\
\hline YED06 & $\begin{array}{l}0.041 \\
(0.107)\end{array}$ & $\begin{array}{l}0.033 \\
(0.107)\end{array}$ & $\begin{array}{l}0.031 \\
(0.107)\end{array}$ & $\begin{array}{l}0.013 \\
(0.108)\end{array}$ \\
\hline YED07 & $\begin{array}{l}0.021 \\
(0.106)\end{array}$ & $\begin{array}{l}0.011 \\
(0.107)\end{array}$ & $\begin{array}{l}0.003 \\
(0.107)\end{array}$ & $\begin{array}{l}-0.016 \\
(0.108)\end{array}$ \\
\hline Tau-a & 0.56 & 0.56 & 0.56 & 0.56 \\
\hline Concordant & $80.31 \%$ & $80.31 \%$ & $80.28 \%$ & $80.59 \%$ \\
\hline Log likelihood & -1316.83 & -1316.62 & -1316.37 & -1310.15 \\
\hline Number of observations & 3083 & 3083 & 3083 & 3081 \\
\hline
\end{tabular}

Note) $* \mathrm{p}<0.1 ; * * \mathrm{p}<0.05 ; * * * \mathrm{p}<0.01$

Standard errors are in parentheses. Industry dummies fixed effects are included and not shown. 
Table 4 Factors affecting export performance (EP)

\begin{tabular}{|c|c|c|c|c|}
\hline \multirow[t]{2}{*}{ Variables } & \multicolumn{4}{|c|}{$E P$} \\
\hline & Model 5 & Model 6 & Model 7 & Model 8 \\
\hline INTERCEPT & $\begin{array}{l}-2.330 * \\
(1.175)\end{array}$ & $\begin{array}{l}-2.677 * * \\
(1.168)\end{array}$ & $\begin{array}{l}-3.016 * * \\
(1.365)\end{array}$ & $\begin{array}{l}-2.942 * * \\
(1.279)\end{array}$ \\
\hline OFFICIAL & & $\begin{array}{l}0.140 \\
(0.122)\end{array}$ & $\begin{array}{l}0.150 \\
(0.145)\end{array}$ & $\begin{array}{l}0.106 \\
(0.132)\end{array}$ \\
\hline$M N C$ & & & $\begin{array}{l}0.503^{* *} \\
(0.226)\end{array}$ & $\begin{array}{l}0.482^{* *} \\
(0.210)\end{array}$ \\
\hline OUTSIDE & & & & $\begin{array}{l}1.014^{* *} \\
(0.457)\end{array}$ \\
\hline SIZE & $\begin{array}{l}0.035 \\
(0.028)\end{array}$ & $\begin{array}{l}0.033 \\
(0.029)\end{array}$ & $\begin{array}{l}0.027 \\
(0.036)\end{array}$ & $\begin{array}{l}0.025 \\
(0.034)\end{array}$ \\
\hline$B O A R D$ & $\begin{array}{l}0.062^{*} \\
(0.026)\end{array}$ & $\begin{array}{l}0.066^{* * *} \\
(0.025)\end{array}$ & $\begin{array}{l}0.064^{* *} \\
(0.029)\end{array}$ & $\begin{array}{l}0.052 * * \\
(0.026)\end{array}$ \\
\hline$M K T$ & $\begin{array}{l}-5.716^{* * *} \\
(2.123)\end{array}$ & $\begin{array}{l}-5.627^{* *} \\
(2.202)\end{array}$ & $\begin{array}{l}-5.524^{* *} \\
(2.709)\end{array}$ & $\begin{array}{l}-5.477^{* *} \\
(2.522)\end{array}$ \\
\hline TECH & $\begin{array}{l}5.243 * * * \\
(0.478)\end{array}$ & $\begin{array}{l}5.278 * * * \\
(0.504)\end{array}$ & $\begin{array}{l}5.344^{* * *} \\
(0.618)\end{array}$ & $\begin{array}{l}5.288 * * * \\
(0.572)\end{array}$ \\
\hline CHAEBOLS & $\begin{array}{l}0.151 \\
(0.112)\end{array}$ & $\begin{array}{l}0.142 \\
(0.116)\end{array}$ & $\begin{array}{l}0.123 \\
(0.143)\end{array}$ & $\begin{array}{l}0.037 \\
(0.138)\end{array}$ \\
\hline LEVERAGE & $\begin{array}{l}0.008 \\
(0.239)\end{array}$ & $\begin{array}{l}0.041 \\
(0.244)\end{array}$ & $\begin{array}{l}0.171 \\
(0.306)\end{array}$ & $\begin{array}{l}0.076 \\
(0.280)\end{array}$ \\
\hline ROIC & $\begin{array}{l}-0.006 \\
(0.005)\end{array}$ & $\begin{array}{l}-0.007 \\
(0.005)\end{array}$ & $\begin{array}{l}-0.008 \\
(0.006)\end{array}$ & $\begin{array}{l}-0.008 \\
(0.005)\end{array}$ \\
\hline$I M R$ & $\begin{array}{l}1.792^{*} \\
(0.938)\end{array}$ & $\begin{array}{l}2.191^{* *} \\
(0.914)\end{array}$ & $\begin{array}{l}2.700^{* * *} \\
(1.042)\end{array}$ & $\begin{array}{l}2.505^{* * *} \\
(0.959)\end{array}$ \\
\hline YED02 & $\begin{array}{l}0.053 \\
(0.153)\end{array}$ & $\begin{array}{l}0.056 \\
(0.165)\end{array}$ & $\begin{array}{l}0.059 \\
(0.203)\end{array}$ & $\begin{array}{l}0.041 \\
(0.188)\end{array}$ \\
\hline YED03 & $\begin{array}{l}0.156 \\
(0.151)\end{array}$ & $\begin{array}{l}0.152 \\
(0.163)\end{array}$ & $\begin{array}{l}0.148 \\
(0.201)\end{array}$ & $\begin{array}{l}0.119 \\
(0.188)\end{array}$ \\
\hline YED04 & $\begin{array}{l}0.265^{*} \\
(0.152)\end{array}$ & $\begin{array}{l}0.271^{*} \\
(0.164)\end{array}$ & $\begin{array}{l}0.272 \\
(0.201)\end{array}$ & $\begin{array}{l}0.230 \\
(0.187)\end{array}$ \\
\hline YED05 & $\begin{array}{l}0.025 \\
(0.151)\end{array}$ & $\begin{array}{l}0.024 \\
(0.162)\end{array}$ & $\begin{array}{l}0.012 \\
(0.200)\end{array}$ & $\begin{array}{l}-0.036 \\
(0.187)\end{array}$ \\
\hline YED06 & $\begin{array}{l}0.038 \\
(0.152)\end{array}$ & $\begin{array}{l}0.042 \\
(0.162)\end{array}$ & $\begin{array}{l}0.043 \\
(0.200)\end{array}$ & $\begin{array}{l}-0.010 \\
(0.186)\end{array}$ \\
\hline YED07 & $\begin{array}{l}0.033 \\
(0.151)\end{array}$ & $\begin{array}{l}0.034 \\
(0.161)\end{array}$ & $\begin{array}{l}0.028 \\
(0.198)\end{array}$ & $\begin{array}{l}-0.026 \\
(0.185)\end{array}$ \\
\hline Number of observations & 3040 & 3040 & 3040 & 3038 \\
\hline
\end{tabular}

Note) $* \mathrm{p}<0.1 ; * * \mathrm{p}<0.05 ; * * * \mathrm{p}<0.01$

Standard errors are in parentheses. Industry dummies fixed effects are included and not shown. 
Table 5 Simultaneous quantile regression estimates for the impact of OFFICIAL, MNC, OUTSIDE

\begin{tabular}{|c|c|c|c|c|c|c|c|c|c|}
\hline & 10th & 20th & 30th & 40th & 50th & 60th & 70th & 80th & 90th \\
\hline \multirow{2}{*}{ SIZE } & 0.000 & 0.001 & 0.000 & -0.001 & 0.002 & $0.014 * *$ & 0.012 & $0.017 *$ & $0.034 * * *$ \\
\hline & $(0.000)$ & $(0.001)$ & $(0.001)$ & $(0.002)$ & (0.004) & $(0.007)$ & $(0.008)$ & (0.009) & $(0.010)$ \\
\hline \multirow[t]{2}{*}{$B O A R D$} & 0.000 & -0.000 & -0.001 & -0.002 & -0.002 & $-0.006^{* *}$ & $-0.008^{*}$ & $-0.007 * *$ & $-0.017 * * *$ \\
\hline & $(0.001)$ & $(0.001)$ & $(0.001)$ & $(0.002)$ & $(0.002)$ & $(0.002)$ & $(0.005)$ & $(0.004)$ & $(0.004)$ \\
\hline \multirow[t]{2}{*}{$M K T$} & 0.000 & $-0.236 * *$ & $-0.892 * * *$ & $-1.657 * * *$ & $-2.649 * * *$ & $-3.402 * * *$ & $-4.409 * * *$ & $-5.564 * * *$ & $-6.129 * * *$ \\
\hline & (0.010) & $(0.117)$ & $(0.142)$ & $(0.237)$ & $(0.286)$ & $(0.374)$ & $(0.406)$ & $(0.431)$ & $(0.449)$ \\
\hline \multirow[t]{2}{*}{ TECH } & 0.000 & 0.023 & 0.470 & 0.705 & 0.990 & 1.769 & 2.627 & $4.811^{*}$ & $7.250^{* *}$ \\
\hline & $(0.061)$ & (0.394) & (0.614) & $(0.952)$ & (1.514) & (2.683) & (3.102) & (2.868) & (2.855) \\
\hline \multirow[t]{2}{*}{ CHAEBOLS } & 0.000 & 0.003 & $0.022 * *$ & $0.068 * * *$ & $0.099 * * *$ & $0.121 * * *$ & $0.101^{* * *}$ & 0.015 & $0.088^{* *}$ \\
\hline & $(0.001)$ & $(0.004)$ & (0.009) & $(0.014)$ & (0.018) & $(0.024)$ & $(0.031)$ & $(0.025)$ & $(0.040)$ \\
\hline \multirow[t]{2}{*}{ LEVERAGE } & 0.000 & 0.010 & 0.020 & 0.042 & 0.042 & 0.025 & 0.034 & -0.062 & -0.038 \\
\hline & (0.000) & $(0.007)$ & (0.019) & $(0.031)$ & (0.043) & $(0.048)$ & (0.074) & (0.079) & $(0.066)$ \\
\hline \multirow[t]{2}{*}{ ROIC } & 0.000 & 0.000 & 0.000 & 0.000 & 0.000 & -0.000 & -0.000 & -0.000 & -0.000 \\
\hline & $(0.000)$ & $(0.000)$ & $(0.000)$ & $(0.000)$ & $(0.000)$ & $(0.000)$ & $(0.000)$ & $(0.000)$ & $(0.000)$ \\
\hline \multirow[t]{2}{*}{ YED02 } & 0.000 & 0.001 & -0.000 & 0.001 & 0.003 & 0.017 & -0.005 & -0.009 & -0.005 \\
\hline & $(0.000)$ & $(0.004)$ & (0.009) & $(0.013)$ & (0.018) & $(0.020)$ & $(0.043)$ & $(0.050)$ & $(0.042)$ \\
\hline \multirow[t]{2}{*}{ YED03 } & 0.000 & 0.002 & -0.002 & 0.005 & 0.005 & 0.045 & 0.009 & -0.011 & -0.034 \\
\hline & (0.000) & $(0.003)$ & (0.005) & $(0.011)$ & (0.019) & (0.029) & $(0.047)$ & (0.038) & $(0.055)$ \\
\hline \multirow[t]{2}{*}{ YED04 } & 0.000 & 0.002 & -0.002 & 0.002 & 0.007 & $0.052 *$ & 0.017 & 0.006 & -0.006 \\
\hline & (0.000) & $(0.004)$ & (0.008) & $(0.018)$ & (0.023) & $(0.030)$ & $(0.051)$ & $(0.053)$ & $(0.049)$ \\
\hline \multirow[t]{2}{*}{ YED05 } & 0.000 & 0.002 & -0.005 & 0.002 & -0.004 & 0.029 & -0.009 & -0.027 & -0.018 \\
\hline & (0.000) & (0.004) & (0.007) & (0.009) & (0.014) & (0.029) & (0.038) & (0.039) & $(0.050)$ \\
\hline \multirow[t]{2}{*}{ YED06 } & 0.000 & 0.000 & -0.003 & -0.011 & -0.000 & 0.014 & -0.032 & -0.039 & -0.036 \\
\hline & $(0.000)$ & $(0.004)$ & (0.010) & $(0.013)$ & $(0.024)$ & $(0.022)$ & $(0.035)$ & $(0.041)$ & $(0.056)$ \\
\hline \multirow[t]{2}{*}{ YED07 } & 0.000 & -0.000 & -0.012 & -0.014 & -0.008 & -0.001 & -0.031 & -0.033 & -0.037 \\
\hline & $(0.000)$ & $(0.004)$ & $(0.010)$ & $(0.013)$ & (0.019) & $(0.028)$ & $(0.045)$ & $(0.051)$ & $(0.057)$ \\
\hline \multirow[t]{2}{*}{ CONSTANT } & 0.000 & -0.032 & -0.042 & -0.038 & -0.127 & $-0.339 * *$ & -0.149 & -0.070 & -0.268 \\
\hline & $(0.000)$ & $(0.015)$ & $(0.032)$ & $(0.066)$ & (0.094) & $(0.163)$ & $(0.207)$ & $(0.239)$ & $(0.274)$ \\
\hline OFFICIAL & 0.000 & 0.002 & 0.009 & $0.030 * * *$ & 0.025 & 0.025 & 0.031 & 0.032 & $0.051^{*}$ \\
\hline (Model 9) & $(0.000)$ & $(0.002)$ & (0.007) & (0.009) & (0.015) & $(0.024)$ & $(0.024)$ & $(0.031)$ & $(0.030)$ \\
\hline$M N C$ & 0.000 & $0.028 * *$ & $0.135 * *$ & $0.250 * * *$ & $0.225 * * *$ & $0.208 * * *$ & $0.194 * * *$ & $0.142 * * *$ & $0.133 * * *$ \\
\hline (Model 10) & $(0.000)$ & $(0.014)$ & $(0.060)$ & $(0.053)$ & $(0.028)$ & $(0.031)$ & $(0.037)$ & $(0.035)$ & $(0.036)$ \\
\hline OUTSIDE & 0.000 & 0.024 & $0.094 * * *$ & $0.198 * * *$ & $0.254 * * *$ & $0.239 * * *$ & $0.346 * * *$ & $0.477 * * *$ & $0.588 * * *$ \\
\hline (Model 11) & $(0.001)$ & $(0.015)$ & $(0.031)$ & $(0.046)$ & $(0.055)$ & $(0.041)$ & $(0.082)$ & $(0.073)$ & $(0.102)$ \\
\hline
\end{tabular}

Note) $* \mathrm{p}<0.1 ; * * \mathrm{p}<0.05 ; * * * \mathrm{p}<0.01$

Number of observations: 3081. Standard errors are in parentheses. Industry dummies fixed effects are included and not shown. 
Figure 1 OFFICIAL coefficients vs. a dense set of quantiles

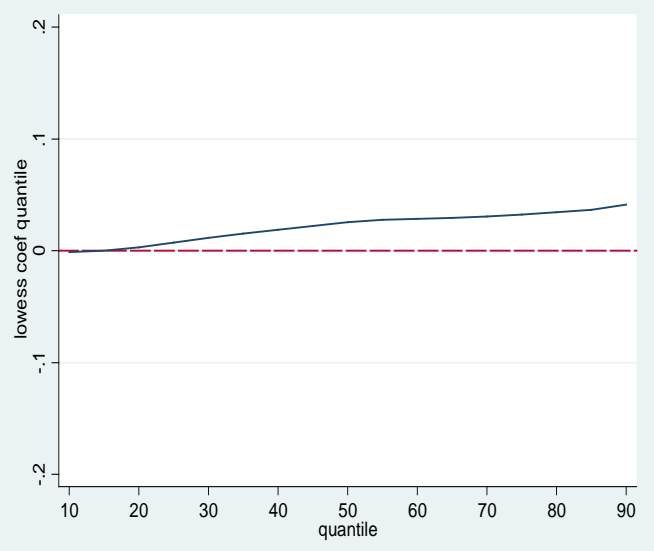

Figure 2 MNC coefficients vs. a dense set of quantiles

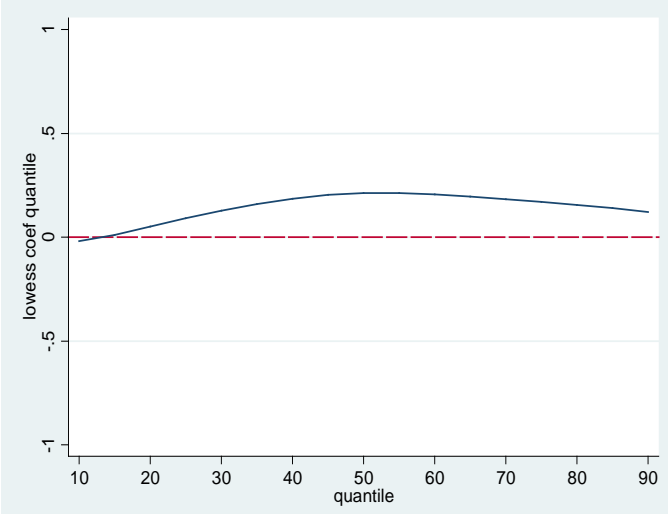

Figure 3 OUTSIDE coefficients vs. a dense set of quantiles

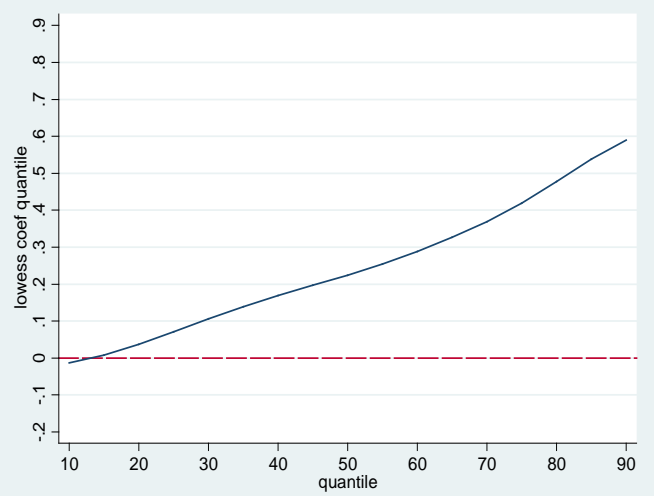

